\title{
An integrated Hydrological Model for Assessing Climate Change Impacts on Water Resources of the Upper Po River Basin
}

\author{
Giovanni Ravazzani • Secondo Barbero • \\ Alessio Salandin • Alfonso Senatore • Marco Mancini
}

\begin{abstract}
Climate change can have profound impacts on water availability. In order to assess the impacts on water resources in complex Alpine river basins, an integrated model that can simulate mutual interactions between natural hydrological processes and anthropogenic disturbances is required. The objective of this study is to show the potential of such an integrated approach in quantifying the impacts of climate change on water resources availability in the Upper Po river basin in Italy. Results show that in the time slice 2041-2050 summer river discharge is expected to decrease with respect to 2001-2010, due to a substantial decrease of seasonal precipitation and an accelerated snow melt that causes an earlier snow depletion. Glaciers volume is expected to decrease to half the current value in 2025, while the minimum elevation of the lowest point of the glaciers is expected to increase from $1890 \mathrm{~m}$ asl to about $2850 \mathrm{~m}$ asl. It is shown that this change can affect regulation of large artificial reservoirs at higher elevation that are mainly dependent on glacier melt for their supply. Increase of annual precipitation is expected to increase groundwater detention that can be used as supplement to diminished river discharge during summer.
\end{abstract}

Keywords Climate change $\cdot$ Hydrological impact $\cdot$ Integrated model

\section{Introduction}

Changes in the water cycle are projected to occur in a warming climate. Changes of average precipitation will not be uniform, with some regions experiencing increases, and others with decreases or not much change at all (Stocker et al. 2013; Ravazzani et al. 2014b).

G. Ravazzani $(\bowtie) \cdot$ M. Mancini

Department of Civil and Environmental Engineering, Politecnico di Milano, Milan, Italy

e-mail: giovanni.ravazzani@polimi.it

S. Barbero $\cdot$ A. Salandin

Regional Environment Protection Agency - ARPA Piemonte, Turin, Italy

A. Senatore

Department of Environmental and Chemical Engineering, Università della Calabria, Arcavacata di Rende, CS, Italy 
Changes in climate can have profound effects on river systems and cause important variation in availability of water (Fiseha et al. 2014; Xu 2000), with significant impacts on uses highly dependent on the hydrological regime, such as hydropower production (Gaudard et al. 2014) and agricultural irrigation (Döll 2002; Senatore et al. 2011).

In the Alpine region, the rising temperatures have resulted in the loss of more than half of the glaciers' volume since 1900 . With a global temperature shifted by $2-4^{\circ}, 50-90 \%$ of the ice's mass coming from mountain glaciers could disappear by the end of this century (Beniston 2012). With earlier snow melting and rainfall variation, inter-annual run-off is changing towards less water during summer and more during winter-season. Depending on the water-shed, the water quantity may increase initially due to the loss of ice stock. However, several case studies show a decrease in runoff in Central Europe (Finger et al. 2012). This would alter the current seasonal cycle of runoff and water levels in regulated reservoirs with possible implications on reservoir operation in order to matching the requirements of sustainable water resources and mitigating the adverse impact of climate variations and changes ( $\mathrm{Li}$ et al. 2010; Veijalainen et al. 2010).

The extreme complexity and heterogeneity of processes involved in river basin hydrology requires the use of integrated modelling approaches for water resources planning and man-agement (Krause and Bronstert 2007) particularly important when dealing with climate change impact analysis (Vansteenkiste et al. 2013; Capell et al. 2014).

River discharges and their temporal distributions are strongly affected by high mountainous areas (Verbunt et al. 2003; Warscher et al. 2013) that are particularly sensitive to global warming (Beniston et al. 2011; Dedieu et al. 2014). Therefore the quality of hydrological impact investigations, even of larger catchments, depends on the capability to model those specific processes in mountainous regions.

On the other hand flow regime of lowland rivers is particularly influenced by surface-groundwater interaction (Ravazzani et al. 2011a). Surface water flowing in streams and groundwater is continuously connected through hyporheic exchange (Bencala et al. 2011; Daniluk et al. 2013). Interaction of stream water and groundwater can take many forms, including groundwater contributions to baseflow, groundwater recharge from effluent streams and rapid bi-directional hyporheic exchange (Winter et al. 1998). In terms of groundwater quantity, climate change affects groundwater systems through both direct and indirect changes (Candela et al. 2009; Zagonari 2010), however, the impacts of climate change on groundwater are slower than the impacts on surface water (Holman 2005).

Furthermore, anthropic structures and practices such as river diversion, lake regulation, and agricultural irrigation, can affect natural flow regime and water cycle in general. This makes an accurate hydrological modelling particularly challenging and require the inclusion of infra-structures and their operations into hydrological models.

Few models can be used for climate change impact analysis on large river basins including simulation of integrated surface-subsurface hydrological processes and anthropogenic influ-ences. The CATHY model (Camporese et al. 2010) is a fully integrated surface-subsurface hydrological that was successfully applied for climate change impact analysis (Sulis et al. 2011). However it lacks capabilities of simulating anthropogenic disturbances, and its detailed structure limits application to moderate sized river basins. The Topkapi-ETH model (Fatichi et al. 2013) is a fully spatially distributed hydrological model capable to reproduce the effect of human operations on discharge, but lacks an integrated description of dynamic interaction with groundwater. The semidistributed SWAT model (Arnold et al. 1993) was integrated with MODFLOW (McDonald and Harbaugh 1988) in order to simulate the interaction between the stream network and the aquifer (Kim et al. 2008). The MIKE-SHE model (Graham and Butts 2005) covers the major processes in the hydrologic cycle including groundwater flow and 
channel flow and their interactions. The coupling with MIKE-BASIN added water allocation, conjunctive use, and reservoir operation modelling capabilities (Christensen 2004). The WaSiM-ETH model (Schulla and Jasper 2007) is a deterministic spatially distributed hydrological catchment model to simulate the water cycle above and below the land surface. It includes irrigation and reservoir management, and external abstractions and inflows.

The novelty of this research is the use of an integrated spatially distributed physically based hydrological model capable to keep into account anthropogenic structures and management practices that interact with natural hydrological cycle such as artificial regulated reservoirs and agricultural irrigation, and interaction of stream and groundwater. This comprehensive model is applied for the first time in a wide and complex study area, with several irrigation districts, regulated reservoirs and a huge anthropogenic impact, such as the upper Po river basin, with the objective of quantifying climate change impacts on water resources availability. This study is part of the ACQWA project (www.acqwa.ch), a largescale integrating project with the goal to use advanced modelling techniques to quantify the influence of climatic change on the major determinants of river discharge at various time and space scales, and analyse their impact on society and economy, also accounting for feedback mechanisms.

The study is performed in three steps: first, the hydrological model FEST-WB is calibrated and validated against observations measured in the control period; second, the performance of the hydrological model in reproducing water balance components during control period driven by climatic forcings is evaluated; and third, the differences in the simulated hydrological impacts as compared to the control period are evaluated and compared.

\section{Material and Methods}

\subsection{Study Area and Data}

The subject area is the Upper Po River basin which covers $38000 \mathrm{~km}^{2}$ (Fig. 1). This is predominantly an alpine region that is bounded on three sides by mountain chains covering $73 \%$ of its territory. While the north-east part of the basin is located in Switzerland, most of it is in the north-west of Italy. Piedmont, located in the Padana Plain, is the principal Italian region in the area while other Italian regions are Aosta Valley, Liguria and Lombardy.

The Upper Po River basin is characterised by a number of fast responding mountainous tributaries from the Alps, flowing into the upper part of the Po River which is flat and contains wide floodplains. The annual regime of the Upper Po River, which is characterized by two low-water periods (winter and summer) and two flood periods (late fall and spring), is strongly influenced by the seasonal pattern of precipitation. The first flood period reflects the intensification of rainstorms in late fall, while the second flood period reflects the contribution of snowmelt processes in the most elevated portions of the catchment.

The plain covers about $25 \%$ of the whole river basin and is characterized by distinctive lithostratigraphical units (Debernardi et al. 2008), listed from top to bottom: 1) alluvial deposits unit usually characterized by gravelly-sandy texture with a thickness ranging between 20 and $50 \mathrm{~m}$ that hosts an unconfined productive aquifer system;2) fluvial-lacustrine deposits unit characterized by alternations of silty-clayey and gravellysandy horizons, which form a confined multi-aquifer system; 3) marine origin sediment unit with fine texture that constitute the substratum of the sediments described above.

Groundwater levels in the shallow unconfined aquifer in the Piedmont plain were moni-tored in June 2002 (Bove et al. 2005). Piezometric lines are generally located parallel to the relief contour and converge in the plain towards watercourses. 


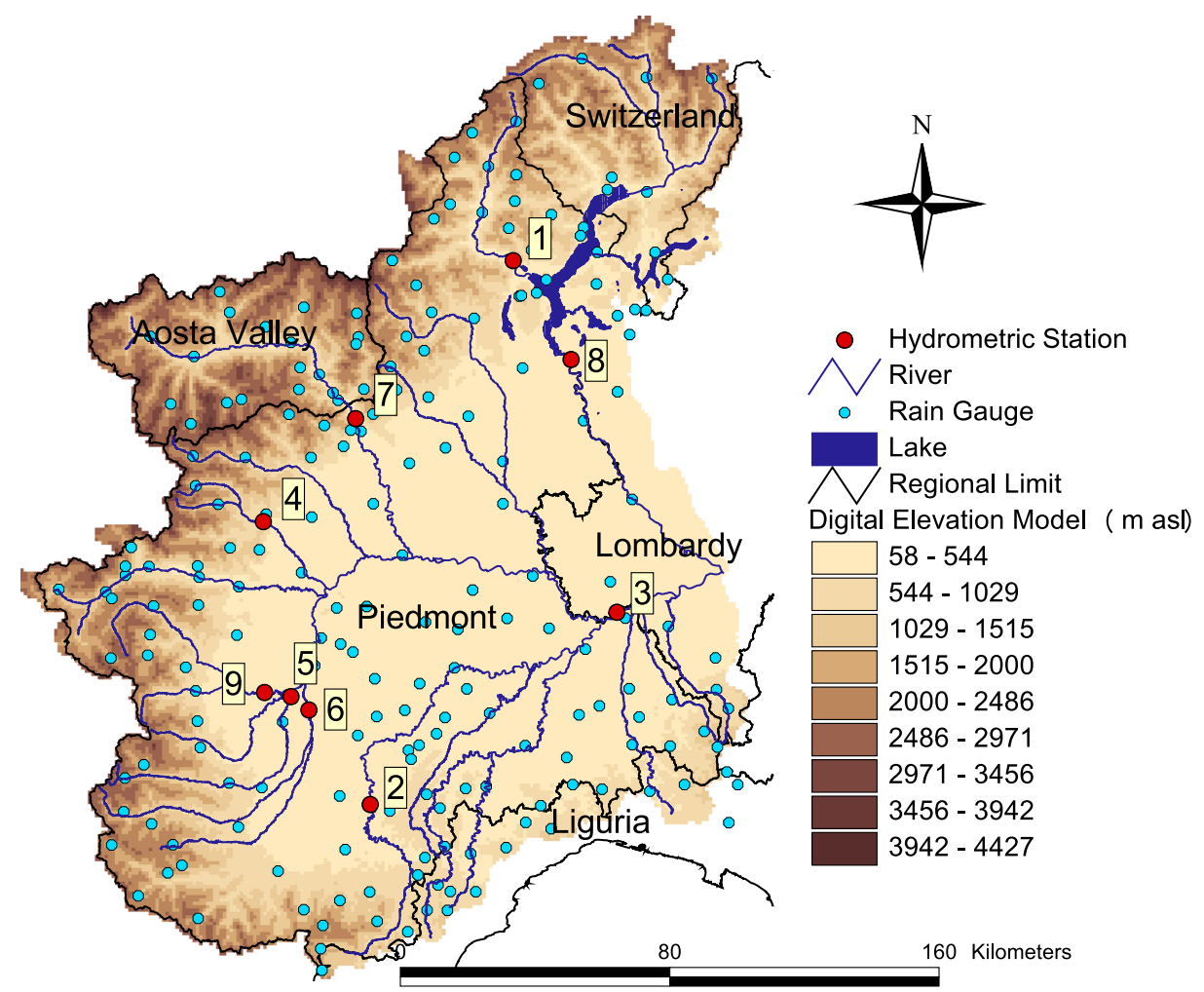

Fig. 1 The Upper Po River basin (area $38000 \mathrm{~km}^{2}$ ) showing locations of the rain gauges and hydrometric stations used in assessing impacts on water resources availability. Hydrometric stations identifiers are shown in Table 1

Agriculture is the main land use, which explains the huge total length of the network of artificial channels over the basin (about $7700 \mathrm{~km}$ ), and specifically the impressive $85 \mathrm{~km}$ long Cavour irrigation canal, which was opened in 1866 and diverts up to $110 \mathrm{~m}^{3} / \mathrm{s}$ from the Upper Po to the Ticino. The irrigated area, shown in Fig. 2, covers a surface of $4500 \mathrm{~km}^{2}$ subdivided in 36 districts managed by as many reclamation and irrigation consortia. Irrigation water supply mainly comes from 21 major river intakes (Fig. 2) and 1035 minor river intakes and partially from groundwater reserves. Seven major lakes are present in the basin and 48 regulated artificial reservoirs (Fig. 2) mainly devoted to hydropower production. Total storage capacity of artificial reservoirs is about $90010^{6} \mathrm{~m}^{3}$.

Meteorological and hydrological data were collected at hourly time step by the telemetric monitoring system managed by Regional Environmental Agencies of Piedmont, Aosta Valley, and Lombardy. Available data include observations from 206 rain gauges, 252 thermometric sensors, and 43 hydrometric stations from 1 January 2000 to 31 December 2010. For the same period, record of daily net inflow to the Lake Verbano obtained from level and release measurements by inverting the reservoir mass balance equation (section 8 in Fig. 1) were provided by the lake regulation authority (Consorzio Ticino).

Available digital cartographic data include: the Digital Elevation Model (DEM) available in raster format at $50 \times 50 \mathrm{~m}$ resolution, CORINE land cover, and pedologic characteristics for 


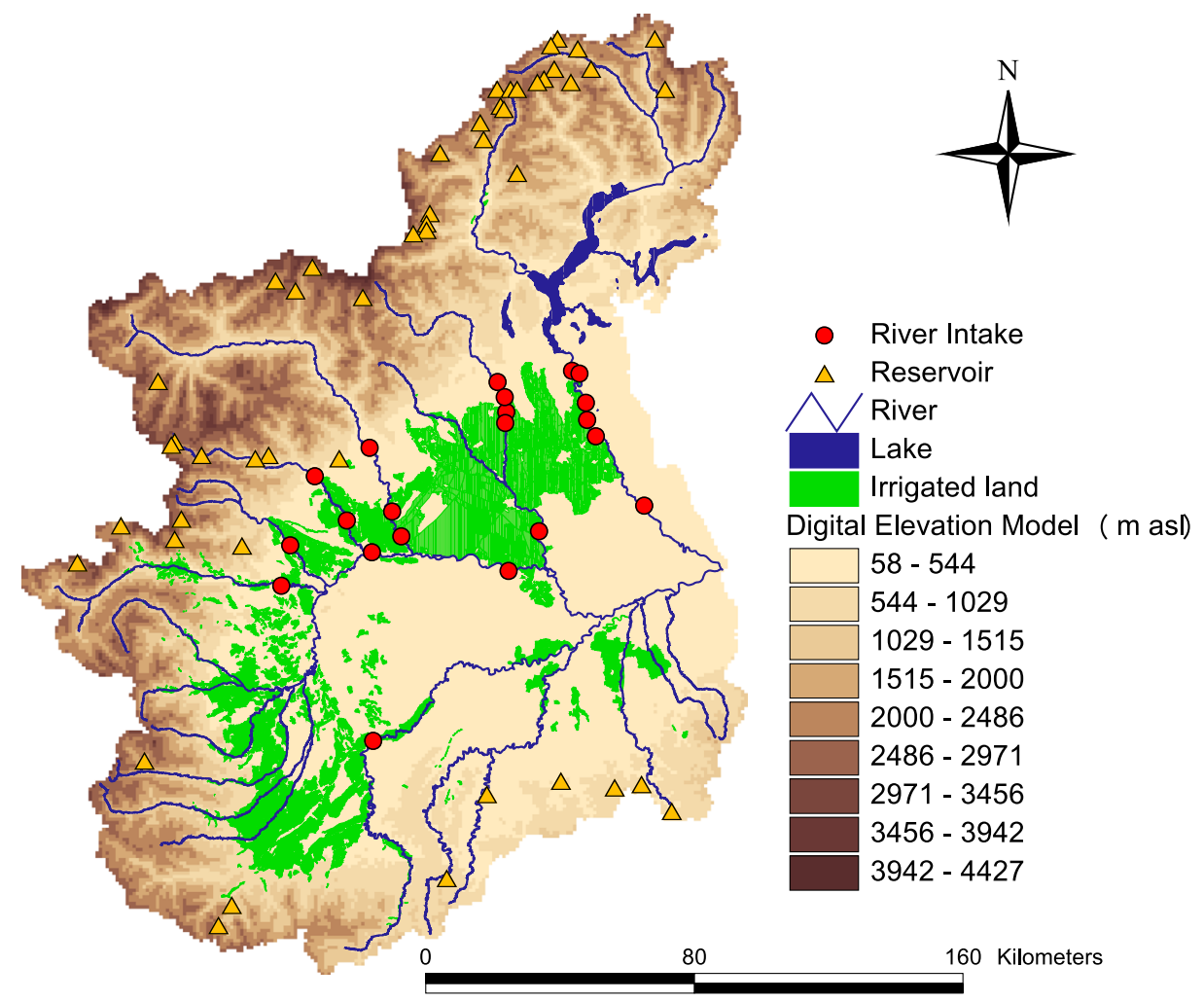

Fig. 2 The Upper Po River basin showing locations of artificial reservoirs, main river intakes, and irrigated area $\left(4500 \mathrm{~km}^{2}\right)$

soils available in vector format. Meteorological forcing variables at 3-hourly time step representative of the future climate were obtained from REMO regional climate model (Jacob 2001) on a $25 \times 25 \mathrm{~km}$ grid, using IPCC's greenhouse gas emission scenario A1B (Nakicenovic et al. 2000). The Quantile Mapping correction approach was applied to remove biases (Themeßl et al. 2012). For further details about climate projections provided within the ACQWA project, the reader can refer to Gobiet et al. (2014).

The impacts of climate change on hydrological processes were assessed by comparing results from the FEST-WB model, driven by the REMO climate projection, for the decade spanning 2041-2050, to those of the control period 2001-2010. The time period 2041-2050 was chosen for assessing climate change impacts because it has the same length of the control period and because differences with respect to current scenario are expected to be more pronounced.

\subsection{Hydrological Model}

For rainfall-runoff transformation we employed the FEST-WB model (flash-Flood Event-based Spatially distributed rainfall-runoff Transformation, including Water Balance)(Rabuffetti et al. 2008; Pianosi and Ravazzani 2010; Ceppi et al. 2013) developed on top of MOSAICO library (Ravazzani 2013). FEST-WB computes the main processes of the hydrological cycle: evapotranspiration, infiltration, surface runoff, flow routing, subsurface flow, and 
snow melt and accumulation (Fig. 3). Evapotranspiration is computed according to a modified version of Hargreaves-Samani equation specifically developed for applications to the Upper Po basin (Ravazzani et al. 2012) and applied to longterm simulation of hydrological balance (Ravazzani et al. 2014a). The computation domain is discretized with a mesh of regular square cells $(1000 \times 1000 \mathrm{~m}$ here $)$ in each of which water fluxes are calculated at hourly time step.

The original model was improved in order to keep into account anthropogenic structures and management practices that interact with natural hydrological cycle such as artificial regulated reservoirs and agricultural irrigation, and interaction of stream and groundwater, such as described below. Further advantage to use this model is that it can ingest time-dimensional gridded dataset of climatic forcings in NetCDF format. If required, maps are converted to appropriate coordinate reference system on the fly.

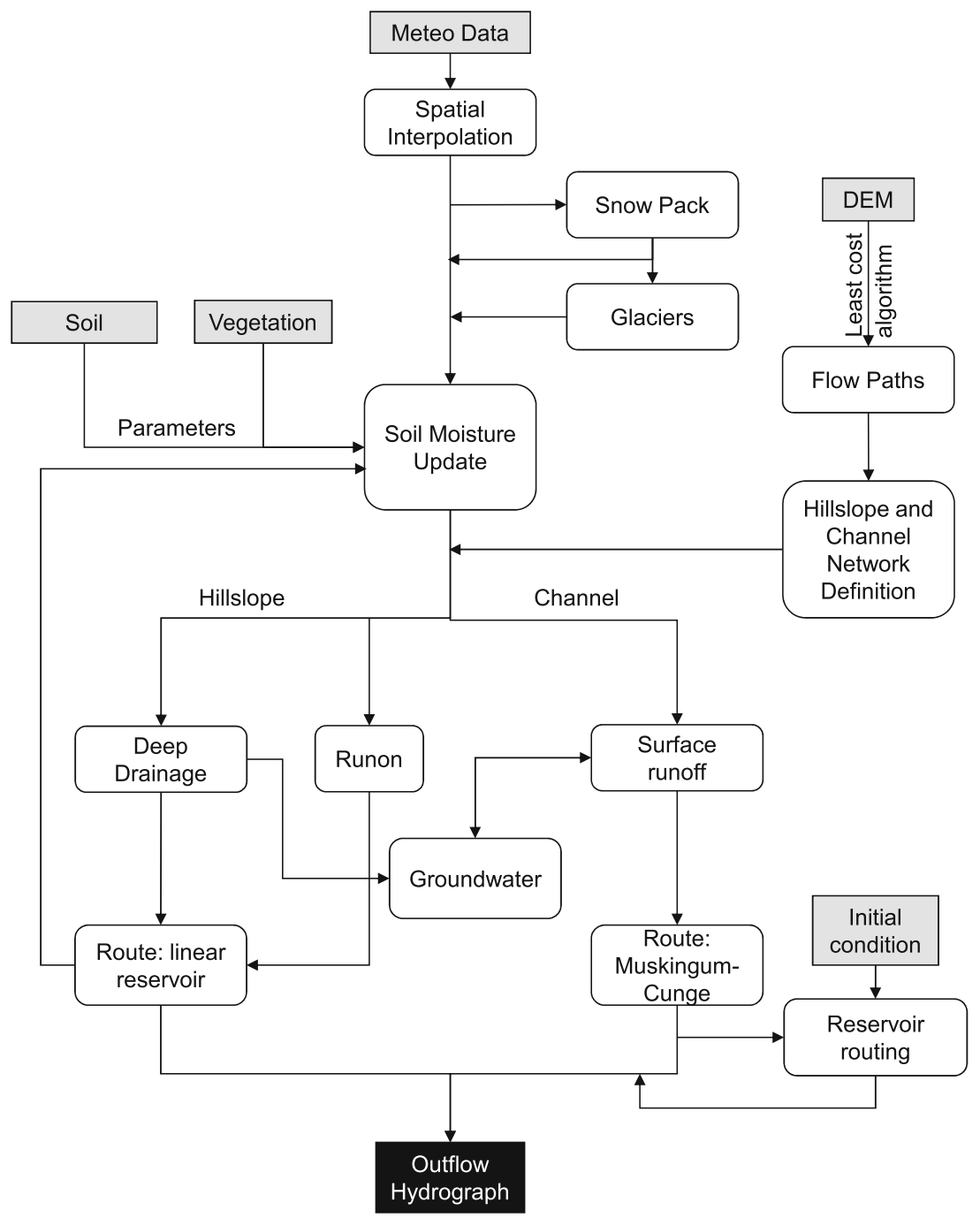

Fig. 3 Scheme of the primary features of FEST-WB distributed-hydrological model 


\subsubsection{Stream-groundwater Interaction}

In order to simulate groundwater flow, the MACCA-GW model by Ravazzani et al. (2011b) was integrated into the FEST-WB hydrological model. The MACCA-GW model is based on macroscopic cellular automata paradigm and was specifically developed for long time simulations, hence it is particularly suited for climate change analyses.

The area modeled by the groundwater model covers the whole river Po plain that was divided into a finite-difference grid with a constant spatial resolution of $1000 \mathrm{~m}$ to match spatial resolution of hydrological model. The groundwater storage was conceptualized as a shallow unconfined aquifer and a deeper confined aquifer separated by an aquitard. Boundary conditions include both Neumann and Dirichlet types (Fig. 4). In Neumann type boundary cells, the subsurface flow coming from hydrological simulation is transformed into a flux entering unconfined aquifer along the border. Dirichlet type boundary condition cells are set along the eastern border of the aquifer that continues downward into the Po valley. Piezometric head assigned to Dirichlet type cells is considered constant in time.

In groundwater domain, percolation depurated from capillary rise computed by hydrological model is transformed into net recharge to groundwater storage.

In all cells adjacent to river network, river interconnection is simulated, which allows stream to gain or lose water. The stream stage is used to calculate the flux between the stream and the aquifer system, proportional to the head gradient between the river and the aquifer and a streambed conductance parameter. When the aquifer head is above the bottom of the streambed, model assumes that the discharge through the streambed is proportional to the difference in hydraulic head between the stream and the aquifer:

$$
Q=\frac{K_{s b} L W}{M}\left(h_{w}-h\right)
$$
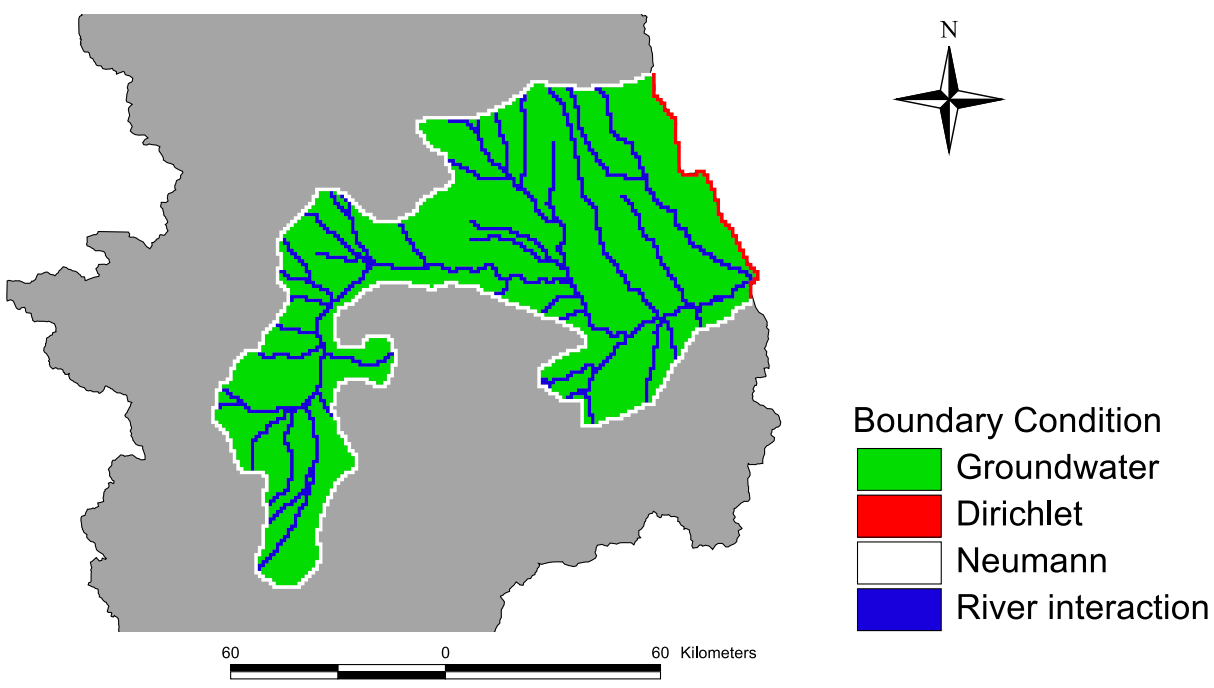

Fig. 4 Aquifer conceptual model: scheme of boundary conditions. In Neumann type boundary cells, the subsurface flow coming from hydrological simulation is transformed into a flux entering unconfined aquifer along the border. Dirichlet type boundary condition cells are set along the eastern border of the aquifer that continues downward into the Po valley 
where $Q$ is the discharge $\left[\mathrm{L}^{3} \mathrm{~T}^{-1}\right]$ with a downward flux assumed positive, $K_{s b}$ is the streambed hydraulic conductivity [ $\left.\mathrm{LT}^{-1}\right], L$ is the stream length [L], $W$ is the stream width [L], $M$ is the streambed thickness [L], $h_{w}$ is the hydraulic head in the stream [L], and $h$ is the hydraulic head in the aquifer [L]. If the aquifer head drops below the bottom of the streambed, the model assumes that the seepage flow is no longer proportional to the aquifer head and becomes dependent on the water level in the stream and the streambed thickness:

$$
Q=\frac{K_{s b} L W}{M}\left(H_{w}+M\right)
$$

where $H_{w}$ is the water level in the stream above the surface of the streambed [L]. At the beginning of each iteration, terms representing river seepage are added to the groundwater flow equation for each cell containing a river reach. Negative seepage occurs when river stage drops below aquifer head. Groundwater seepage is added to or subtracted from river flow accordingly.

\subsubsection{Regulated Reservoirs}

Flow routing through a reservoir is described using the third-order Runge-Kutta method (Carnahan et al. 1969; Chow et al. 1988; Ravazzani et al. 2014c). Relationship between reservoir water level and outflow is assigned as a lookup table for a finite number of values. Intermediate values are found by linear interpolation.

In the present analysis, reservoirs are operated according to a target-level policy. A target level was assigned for each reservoir and for each day of the year. In case the actual simulated reservoir level exceeds the target level, water is released from the reservoir at the rate corresponding to the given level. In case the simulated reservoir level is lower than the target level only the environmental flow is released from the reservoir. Target levels were derived from observations as long-term averages of reservoir levels for a given day of the year. Target levels are considered unvarying throughout the whole analysis period.

For further details about regulation policy the reader can refer to Fatichi et al. (2013).

\subsubsection{Irrigation}

The abundance of water has been a very important resource for the development of the Upper Po basin. A complex network of channels dating back, in some cases, to the XII $^{\text {th }}$ century allows water transfer for irrigation from the Po river and its tributaries at the foothills of the Alps, downstream the large Alpine lakes, downwards, to the very productive plains of the Po river basin. The network of irrigation channels is very dense and was implemented along the centuries. Irrigation methods are different but prevailing techniques are surface irrigation or furrow irrigation. With-drawals time series from river network are not measured. The only available infor-mation is the concession discharge and the period in which water can be withdrawn from the main river intakes (Fig. 2).

The simplification of irrigation rules in the model assumes that all available flow in the river minus the environmental flow is withdrawn until satisfaction of concession discharge and uniformly distributed on the irrigated area connected to the serving intake. Irrigation is activated only when mean soil moisture content of the irrigated district is below a given threshold. The irrigation period is assumed from May to August. Irrigation rules and soil uses are considered constant throughout the climate change analysis. 


\subsection{Models Calibration and Validation}

The hydrological model was calibrated against available observations, namely satellite re-motely sensed snow cover images and river discharge.

Calibration of the snow model parameters was based on the comparison of simulated snow cover percentage with the one retrieved from satellite images. Results are presented in Boscarello et al. (2014).

The values of soil related parameters were defined starting from pedologic map, and assigning a specific value of each parameter for each cell in relation to texture class of the input map.

In order to tune performance of the hydrological model in simulating river discharge, 9 sections, listed in Table 1 and shown in Fig. 1, were selected for the accuracy and completeness of the available dataset, and considered representative of the river basins in this area. Simulation period was split into a calibration period, from 2001 to 2005, and a validation period, from 2006 to 2010 . The year 2000 was treated as the period for the model initialization. Considering the calibration period, soil saturated hydraulic conductivity was changed with the object to minimize error in reproducing river discharge observations. To this purpose, the conductivity value in each cell is split into two component: one fixed, the initial value, that expresses the spatial pattern and the physical meaning, and one variable, the correction factor, that takes into account all the modeling errors (Francés et al. 2007). This method allows to maintain both the spatial variability described a priori and the physical meaning of parameters, allowing the calibration procedure to modify the correction factors only in the admissible range of variability. All available meteorological observations were used as input to hydrological simulations. Further details about calibration method are given in Boscarello et al. (2013). The model performance criteria used are: the coefficient of variation of the root mean square error $(C V(R M S E))$, and the Nash and Sutcliffe efficiency $(\eta)$ (Nash and Sutcliffe 1970), defined as follows:

$$
C V(R M S E)=\frac{\left[\frac{\sum_{i=1}^{n}\left(Q_{\text {sim }}^{i}-Q_{o b s}^{i}\right)^{2}}{n}\right]^{0.5}}{\overline{Q_{o b s}}}
$$

Table 1 River basins considered in the investigation of climate change impacts

\begin{tabular}{lllr}
\hline Id & Section & River & Area $(\mathrm{km} 2)$ \\
\hline 1 & Candoglia & Toce & 1589 \\
2 & Farigliano & Tanaro & 1549 \\
3 & Isola S. Antonio & Po & 26167 \\
4 & Lanzo & Stura di Lanzo & 652 \\
5 & Polonghera & Varaita & 626 \\
6 & Racconigi & Maira & 1168 \\
7 & Tavagnasco & Dora Baltea & 3420 \\
8 & Verbano & Ticino & 6831 \\
9 & Villafranca & Pellice & 1026 \\
\hline
\end{tabular}




$$
\frac{\eta=1-\sum_{i=1}^{n}\left(Q_{s i m}^{i}-Q_{o b s}^{i}\right)^{2}}{\sum_{i=1}^{n}\left(Q_{o b s}^{i}-\overline{Q_{o b s}}\right)^{2}}
$$

where $n$ is the total number of time steps, $Q_{\text {sim }}^{i}$ is the $i$ th simulated discharge, $Q_{o b s}^{i}$ is the $i$ th observed discharge, and $\overline{Q_{o b s}}$ is the mean of the observed discharges.

Further validation of the hydrological model, was performed by comparing mean monthly simulated to mean monthly observed discharge, in the period 2001-2010. This criterion was decided as mean monthly discharge was used for assessing climate change impacts on flow regime (Section 3.5). Model performance was considered acceptable when mean monthly discharge bias was lower than $25 \%$ considered as the mean error associated to discharge measurement in the Po river basin (Di Baldassarre and Montanari 2009).

Further validation was performed on hydrological model forced by meteorological variables projected by climate model, in reproducing mean monthly discharge simulated with observed meteorological forcings, in the control period 2001-2010. The coefficient of variation of the root mean square deviation $(C V(R M S D))$ was used as performance criterion:

$$
C V(R M S E)=\frac{\left[\frac{\sum_{i=1}^{12}\left(Q_{\text {sim,aws }}^{i}-Q_{\text {sim }, \text { cli }}^{i}\right)^{2}}{12}\right]^{0.5}}{\overline{Q_{\text {sim }, \text { aws }}}}
$$

where $Q_{\text {sim,aws }}^{i}$ is the $i$ th mean monthly discharge simulated by using meteorological observations from automatic weather stations, $Q_{s i m, c l i}^{i}$ is the $i$ th mean monthly discharge simulated by using meteorological forcings from climate model, and $\overline{Q_{\text {obs,aws }}}$ is the average of mean monthly discharges simulated by using meteorological observations.

\section{Results and Discussion}

The results of the regional climate modeling and the hydrological simulations are presented below. First, performance of the climate and the hydrological models is evaluated by comparing the simulated data of the control period (2001-2010) with weather and hydrological data recorded by the Regional Meteo-Hydrological Service.

Impacts of climate change on hydrological balance, glaciers, flow regime and irrigation water supply, regulated reservoirs, and groundwater detention are then presented in specific sections.

\subsection{Calibration and Validation of Hydrologic Model}

In this section results for the calibration and validation of the FEST-WB hydrological model is presented.

Table 2 shows the coefficient of variation of the root mean square error and Nash and Sutcliffe efficiency obtained in the 9 sections in the calibration period (2001-2005), validation period (2006-2010), and entire period (2001-2010). Model shows reasonably satisfactory results with $C V(R M S E)$ ranging from 0.61 to 0.89 , and from 0.64 to 0.83 , in the calibration and 
Table 2 Coefficient of variation of the root mean square error (CV(RMSE)) and Nash and Sutcliffe efficiency $(\eta)$, obtained in the calibration period (2001-2005), validation period (2006-2010) and the entire period (20012010) for the nine sections

\begin{tabular}{|c|c|c|c|c|c|c|}
\hline \multirow[t]{2}{*}{ Id } & \multicolumn{2}{|c|}{ Calibration (2001-2005) } & \multicolumn{2}{|c|}{ Validation (2006-2010) } & \multicolumn{2}{|c|}{ Total (2001-2010) } \\
\hline & $C V(R M S E)$ & $\eta$ & $C V(R M S E)$ & $\eta$ & $C V(R M S E)$ & $\eta$ \\
\hline 1 & 0.66 & 0.63 & 0.52 & 0.71 & 0.58 & 0.67 \\
\hline 2 & 0.64 & 0.76 & 0.79 & 0.68 & 0.77 & 0.69 \\
\hline 3 & 0.68 & 0.64 & 0.76 & 0.61 & 0.73 & 0.62 \\
\hline 4 & 0.71 & 0.57 & 0.72 & 0.76 & 0.72 & 0.71 \\
\hline 5 & 0.88 & 0.45 & 0.81 & 0.53 & 0.84 & 0.48 \\
\hline 6 & 0.82 & 0.54 & 0.83 & 0.51 & 0.83 & 0.52 \\
\hline 7 & 0.61 & 0.77 & 0.64 & 0.73 & 0.63 & 0.75 \\
\hline 8 & 0.89 & 0.59 & 0.69 & 0.69 & 0.79 & 0.65 \\
\hline 9 & 0.65 & 0.63 & 0.71 & 0.59 & 0.67 & 0.60 \\
\hline
\end{tabular}

validation period respectively, and $\eta$ ranging from 0.59 to 0.77 , and from 0.51 to 0.76 , in the calibration and validation period respectively.

Figure 5 shows the results in reproducing the mean monthly streamflow by the FEST-WB model after calibration, forced by meteorological observations. The simulated and observed mean discharge are similar in all the examined sections. Difference between simulated and observed mean monthly discharge is lower than the $25 \%$ intrinsic error in measuring discharge, displayed as grey band on plots. This means that the hydrological model can simulate dominant natural hydrological processes and anthropogenic disturbances as well.

Flow regime in both observed and simulated streamflow is characterized by a peak during spring due to the joint contribution of precipitation and snow and glaciers melt. A secondary peak is observed in late autumn as a consequence of a peak in the precipitation. River basins belonging to Maritime and Ligurian Alpine area in the south western part of the Upper Po basin (sections 2, 5, 6, and 9) are characterized by lower specific discharge in agreement with the precipitation distribution, showing high values in the north gradually reducing facing to south. Moreover, these basins are generally characterized by higher value of evapotranspiration that limits river flow.

Figure 6 shows the result in reproducing the reference unconfined isopiezometric lines monitored in June 2002. The hydrological model properly simulated the pattern of groundwater flux directions including the impact of water courses on draining water from the aquifer.

\subsection{Validation of Climate Model for Contemporary Climate Simulations}

Before assessing the climate change impacts, we performed an analysis of the hydrological model driven by modelled climatic forcings in reproducing the hydrological features of the control period (2001-2010). Mean annual precipitation and average temperature over the Isola S. Antonio river basin (section 3) deviate from observations 0.06 and $-0.02{ }^{\circ} \mathrm{C}$, respectively.

Mean monthly precipitation and temperature for the control period (2001-2010) reproduced by REMO model are presented in Fig. 7, as well as mean monthly discharge simulated by FEST-WB model driven by climatic scenario. Concerning precipitation, REMO model shows overestimation for January, March, July and October and underestimation in 

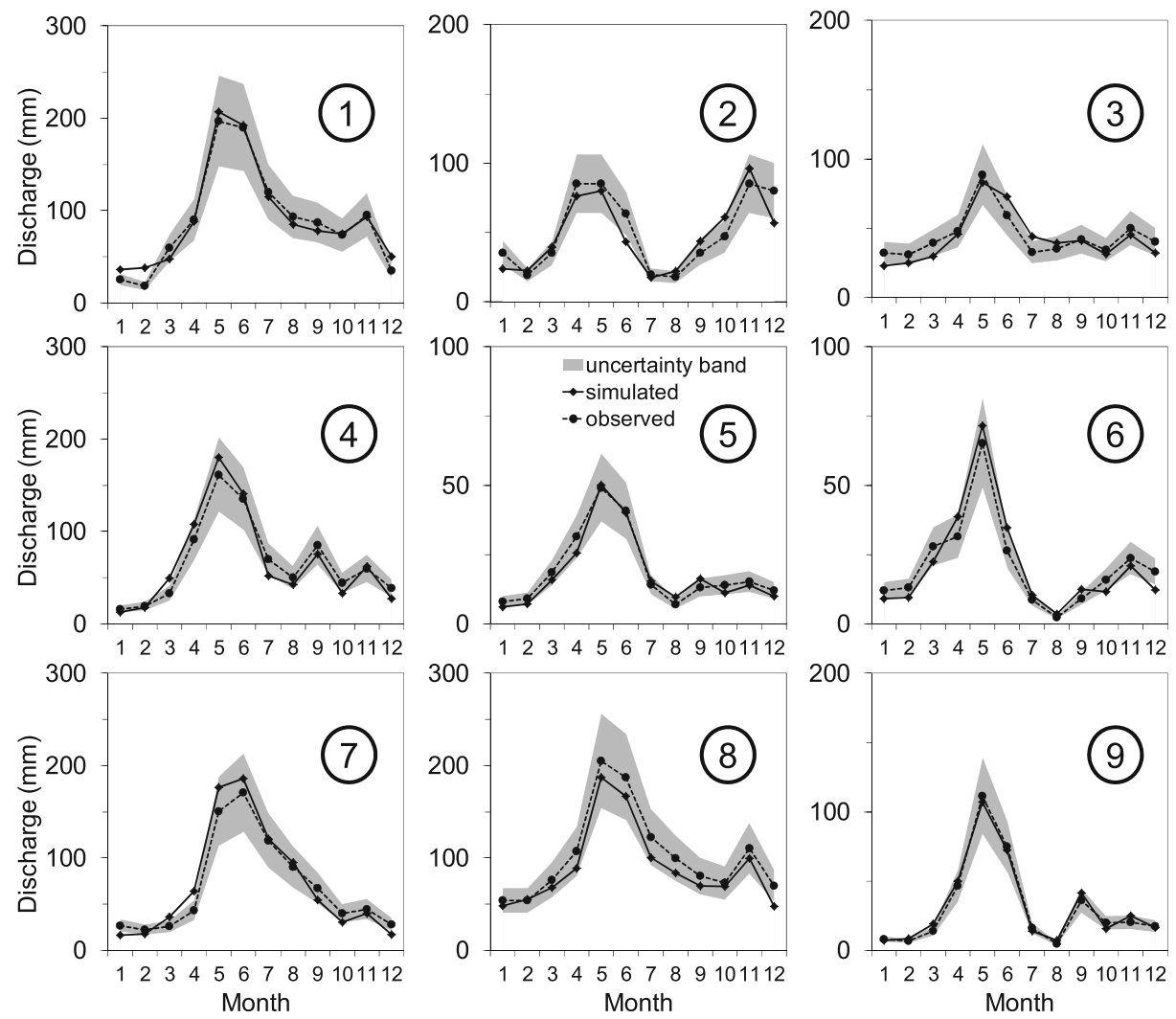

Fig. 5 Mean monthly streamflow for 2001-2010 from observed discharge and simulated by FEST-WB model after calibration, forced by meteorological observations. Grey area shows $25 \%$ error band used to assess model performance

May, September, and December. Nevertheless, the overall behavior, such as the peaks in the spring and autumn, is well captured.

Monthly temperature is overestimated in winter and underestimated from late spring to end of summer. As a consequence of differences between observed and simulated meteorological forcings, mean monthly discharge is overestimated in March and April, and underestimated in September, November, and December, but discharge hydrological regime is reasonably well reproduced. However, future climate change impacts are calculated considering the (already bias corrected) climate scenarios from the regional climate model. Hence, there's no need to consider the error generated with respect to control simulations (this is relevant only before adopting bias correction procedures). The values of $C V(R M S D)$ of the mean monthly discharge for the nine sections investigated are reported in Table 3. Deviation is minimum for the largest basin considered, river Po at Isola S. Antonio, and increases for smaller basins, but remains within reasonably acceptable limits.

\subsection{Elevational Dependence Impacts on Snow and Evapotranspiration}

The impact of climate change on hydrological balance is assessed by comparing snow water equivalent and actual evapotranspiration from the FEST-WB model driven by REMO climate 

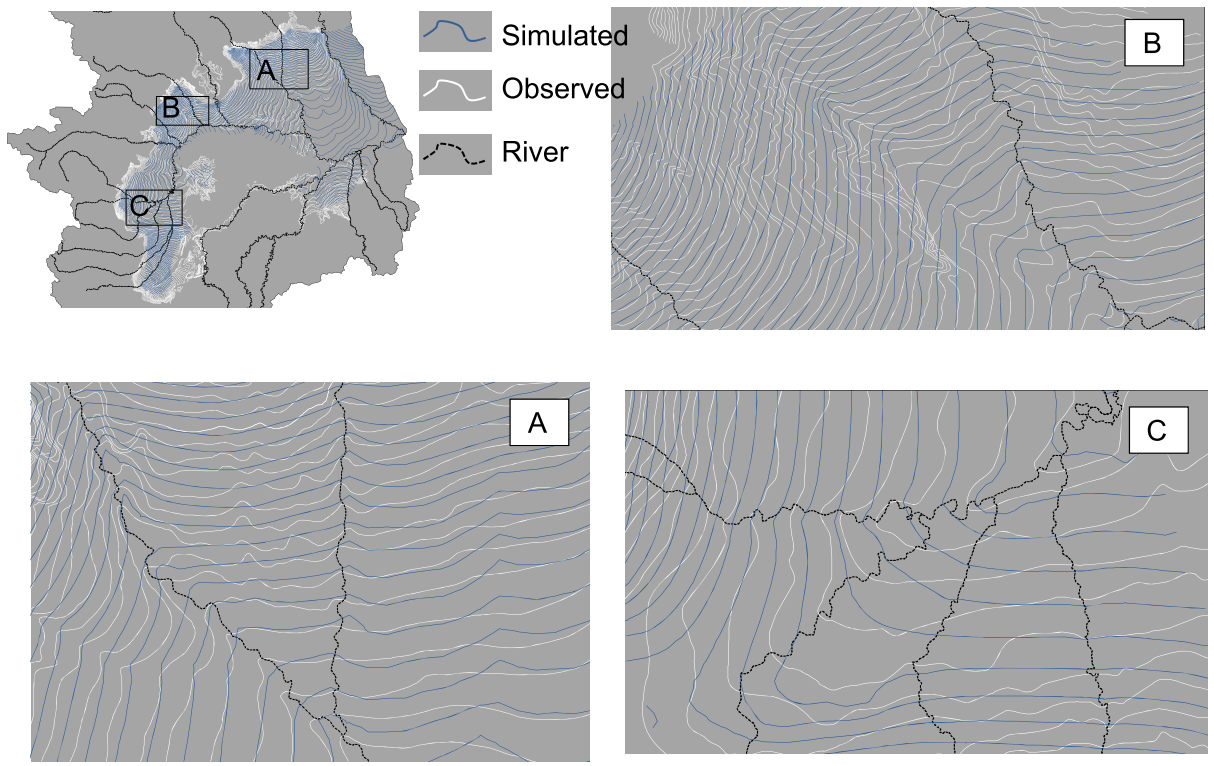

Fig. 6 Comparison between $5 \mathrm{~m}$ interval isopiezometric lines of unconfined aquifer monitored during June 2002 field campaign (white lines) and the ones simulated by the FEST-WB hydrological model (blue lines)

model for the decade spanning 2041-2050 to those of the control period. Three altitude ranges are considered:

- high altitude, with elevation above $1000 \mathrm{~m}$ asl; covered area $14300 \mathrm{~km}^{2}$ (38\% of the total basin);

- intermediate altitude, with elevation ranging from 1000 to $300 \mathrm{~m}$; covered area 11 $100 \mathrm{~km}^{2}$ (29\% of the total basin)

- low altitude, with elevation below $300 \mathrm{~m}$; covered area $12600 \mathrm{~km}^{2}$ (33\% of the total basin).

Table 4 shows the mean annual precipitation and temperature simulated by REMO model and evapotranspiration simulated by the FEST-WB model for the two decades 2001-2010 and 2041-2050 and the three elevation ranges. The mean monthly precipitation and temperature as simulated by REMO for the control period (2001-2010) and the 2041-2050 decade are shown in Fig. 8. Figure 9 shows the mean monthly snow water equivalent and actual
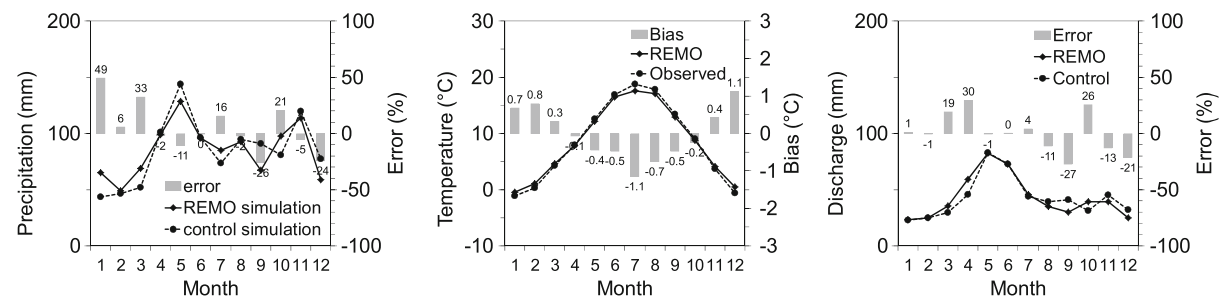

Fig. 7 Mean monthly precipitation and temperature for 2001-2010 for section 3 (Isola S. Antonio) from observations and simulated by REMO model and mean monthly discharge simulated by FEST-WB driven by observed time series and by the climate model 
Table 3 Coefficient of variation of the root mean square deviation $(C V(R M S D))$ obtained by hydrological model forced by meteorological variables coming from climate model, in reproducing mean monthly discharge simulated with observed meteorological forcings in the control period (2001-2010), for the nine sections

\begin{tabular}{ll} 
Section Id & $C V(R M S D)$ \\
\hline 1 & 0.42 \\
2 & 0.45 \\
3 & 0.15 \\
4 & 0.35 \\
5 & 0.43 \\
6 & 0.45 \\
7 & 0.41 \\
8 & 0.34 \\
9 & 0.36
\end{tabular}

evapotranspiration as computed by the FEST-WB model driven by REMO for the control period (2001-2010) and the 2041-2050 decade.

The REMO model simulates an increase in temperature of $1.2,1.3$, and $1.4{ }^{\circ} \mathrm{C}$, respectively, and an increase in the mean annual precipitation of $11.3,7.8$, and $5.3 \%$, respectively.

The precipitation increase is mostly concentrated in the winter period and October. During spring and summer the climate model predicts a remarkable decrease in precipitation, as much as $-27 \%$ in August for high altitude range. The temperature is generally predicted to increase more during the summer and late spring, while a decrease is expected in March. An increase of snow water equivalent is expected in winter and early spring compensated in late spring by an accelerated melt rate. An increase of actual evapotranspiration ranging from 3 to $4 \%$ is expected on annual basis. This increase seems low in respect to the increase of temperature due to the fact that in summer, when major increase of potential evapotranspiration is expected, precipitation and consequently soil moisture decrease. As during summer actual evapotranspiration is limited by soil moisture conditions, the increase of potential evapotranspiration does not necessarily reflect an increase of actual evapotranspiration. In August, in fact, a decrease of actual evapotranspiration is expected.

\subsection{Impacts on Glaciers}

The impact of climate change on glaciers is assessed by analysing expected time series of ice volume and elevation of the lowest point of the glaciers.

Glaciers cover $0.56 \%$ of Upper Po river basin that corresponds to a volume of $9.610^{9} \mathrm{~m}^{3}$ equivalent water. Glaciers are mostly concentrated in Aosta Valley, within the Tavagnasco river basin (section 7), where percentage of area covered with ice rises to $4.8 \%$, that corresponds to a volume of $7.910^{9} \mathrm{~m}^{3}$. Thus glaciers within the Tavagnasco river basin contribute for about $83 \%$ to total glacier volume over the entire Upper Po river basn.

Table 4 Mean annual precipitation, $P$, temperature, $T$, and evapotranspiration, $E T$, for the three altitude ranges, $Z$, and the two decades 2001-2010 and 2041-2050

\begin{tabular}{|c|c|c|c|c|c|c|c|c|c|}
\hline \multirow{2}{*}{$\begin{array}{l}\text { Altitude range } \\
\text { (m asl) }\end{array}$} & \multicolumn{3}{|c|}{$\mathrm{P}(\mathrm{mm})$} & \multicolumn{3}{|l|}{$\mathrm{T}\left({ }^{\circ} \mathrm{C}\right)$} & \multicolumn{3}{|c|}{$\mathrm{ET}(\mathrm{mm})$} \\
\hline & $01-10$ & $41-50$ & $\%$ difference & $01-10$ & $41-50$ & Difference & $01-10$ & $41-50$ & $\%$ difference \\
\hline$Z>1000$ & 1282 & 1427 & $+11.3 \%$ & 2.9 & 4.1 & +1.2 & 250 & 260 & $+4.0 \%$ \\
\hline $300<Z<1000$ & 855 & 922 & $+7.8 \%$ & 11.2 & 12.5 & +1.3 & 223 & 230 & $+3.1 \%$ \\
\hline$Z<300$ & 715 & 753 & $+5.3 \%$ & 12.6 & 14 & +1.4 & 226 & 235 & $+4.0 \%$ \\
\hline
\end{tabular}



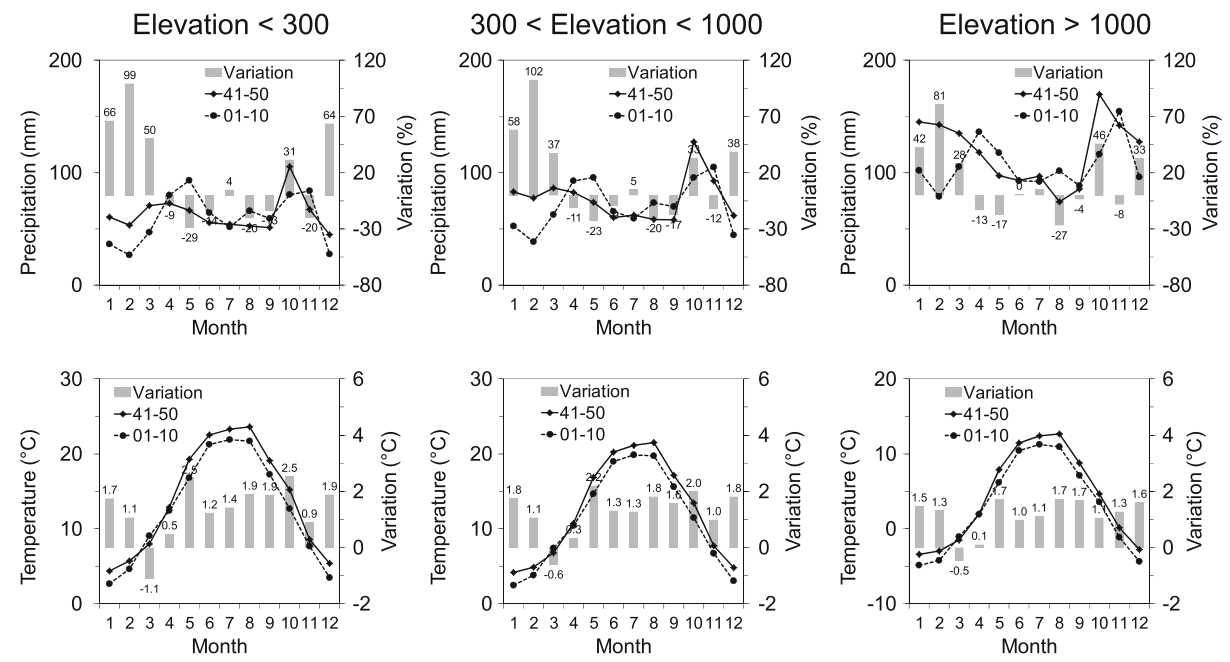

Fig. 8 Mean predicted monthly precipitation and temperature for 2041-2050 as simulated by REMO model compared to those simulated for 2001-2010 for the three altitude ranges: high altitude (elevation above $1000 \mathrm{~m}$ asl), intermediate altitude (elevation ranging from 1000 to $300 \mathrm{~m}$ asl), and low altitude (elevation below $300 \mathrm{~m}$ asl)

Analysis of historical data presented in Diolaiuti et al. (2012) showed that glaciers of Aosta Valley were characterized by a significant loss of area with an acceleration in the recent period (1999-2005), due to increasing temperature especially during late spring and summer, and substantially unchanged total precipitation, with marked reduction of snowfall, snow cover, number of snowfall events and duration of continuous snow cover, especially during spring and summer.
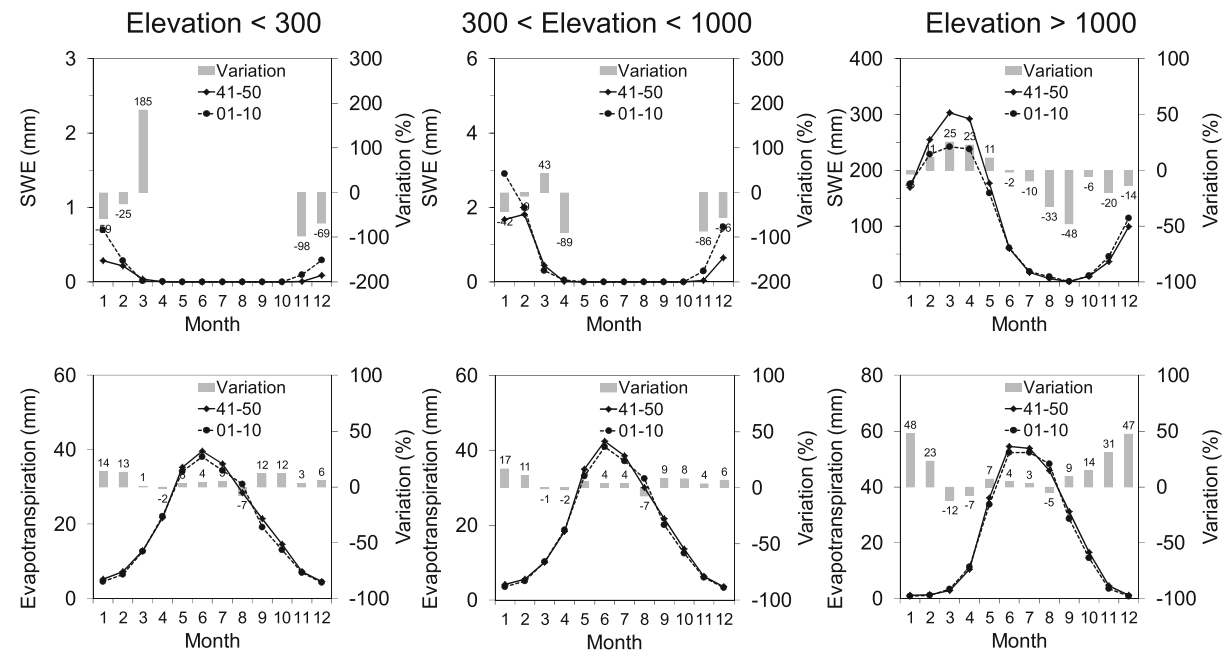

Fig. 9 Mean predicted monthly snow water equivalent and evapotranspiration for 2041-2050 as simulated by FEST-WB model driven by climate scenario compared to those simulated for 2001-2010 for the three altitude ranges: high altitude (elevation above $1000 \mathrm{~m}$ asl), intermediate altitude (elevation ranging from 1000 to $300 \mathrm{~m}$ asl), and low altitude (elevation below $300 \mathrm{~m}$ asl) 
Simulation performed in this study shows a constant decrease of glaciers volume till about 2025 (Fig. 10). The minimum elevation of the lowest point of the glaciers over the Upper Po river basin is expected to increase from $1890 \mathrm{~m}$ asl in 2001 to about $2850 \mathrm{~m}$ asl after 2025 . After 2025 glaciers volume seems to reach a new equilibrium around $5.710^{9} \mathrm{~m}^{3}$. No more increase of minimum glaciers elevation is expected after 2025.

\subsection{Impacts on Flow Regime and Irrigation Water Supply}

The impact of climate change on flow regime is assessed by comparing mean monthly discharges from FEST-WB model driven by REMO climate model for the decade spanning 2041-2050 to those of the control period. Three river basins are considered: river Dora Baltea at Tavagnasco (section 7) representative of nivo-glacial alpine basin, river Pellice at Villafranca (section 9) representative of Maritime Alps, and river Po as Isola S. Antonio (section 3) representative of the whole Upper Po basin.

In Fig. 11, the mean monthly discharge for the 2041-2050 decade is compared to that of the control period (2001-2010). The seasonal shift observed in the precipitation is reflected in the predicted monthly discharge, with a remarkable increase expected in the winter $(279 \%$ increase in February at Villafranca) and autumn and a remarkable decrease expected in the summer $(-53 \%$ in August at Tavagnasco).

The increase of snow water equivalent in winter is not sufficient to compensate the decrease of discharge in summer as the snow accumulation is subject to an accelerated melt rate so that its contribution to summer discharge is negligible. Snow melt affects discharge in May and June that, in fact, is expected to increase despite a decrease in precipitation.

Flow regime shift may cause direct impact on irrigation that is mostly supplied by river flow diversions. In Fig. 12 the mean monthly irrigation water supply and soil moisture of irrigated land for the 2041-2050 decade is compared to that of the control period (2001-2010). The remarkable decrease of river flow in the summer drastically reduces the amount of water available for irrigation ( $-48 \%$ in August). This explains the decrease of water supply in the same period when irrigation is fundamental for crop yield preservation.

\subsection{Impacts on Artificial Reservoirs}

The impact of climate change on artificial reservoirs is assessed analysing expected water surface elevation of two dams devoted to hydropower production: the Sabbione dam, located

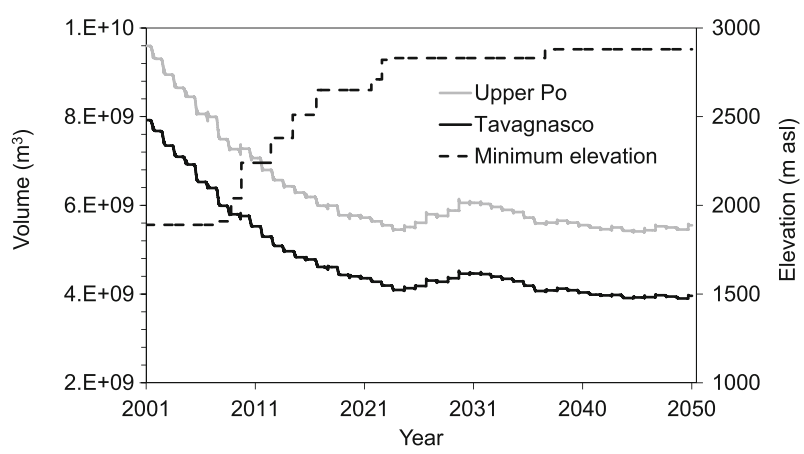

Fig. 10 Glaciers volume for Tavagnasco and Upper Po river basins and minimum elevation of the lowest point of the glaciers as simulated by FEST-WB model driven by climate scenario 

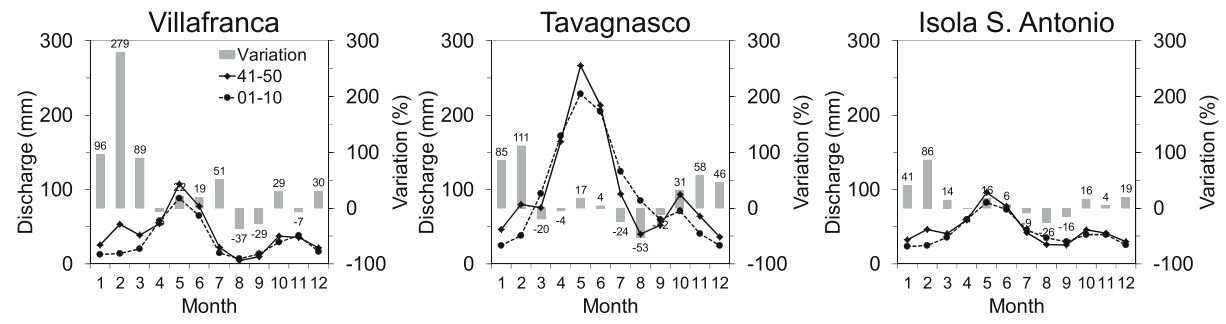

Fig. 11 Mean predicted monthly discharge for 2041-2050 as simulated by FEST-WB model driven by climate scenario compared to those simulated for 2001-2010 for the three sections: river Dora Baltea at Tavagnasco representative of nivo-glacial alpine basin, river Pellice at Villafranca representative of Maritime Alps, and river Po as Isola S. Antonio representative of the whole Upper Po basin

at $2460 \mathrm{~m}$ asl, with effective storage capacity of $2510^{6} \mathrm{~m}^{3}$ and drainage basin of $19 \mathrm{~km}^{2}$, and the Campliccioli dam, located at $1360 \mathrm{~m}$ asl, with effective storage capacity of $8.710^{6} \mathrm{~m}^{3}$ and drainage basin of $34 \mathrm{~km}^{2}$. Sabbione dam derives water supply from ice-melt of two glaciers, while Campliccioli dam is mainly supplied by rain-fed streams. Sabbione water surface elevation shows a maximum in September, just before the termination of glacier-melt, and a minimum in April, just before glacier-melt contribution increases again. Campliccioli water surface elevation shows a maximum in June and November, when contribution of precipitation and snow-melt on stream runoff is important, and a minimum in March.

In Fig. 13 the simulated and target stages within Sabbione and Campliccioli dams are reported for the two decades spanning 2001-2010 and 2041-2050. Results show that water surface elevation within Sabbione dam in 2041-2050 is expected to decrease: in 5 years out of 10, the maximum reservoir filling is not reached. This is due to the glaciers depletion that causes the disappearance of ice mass at lower elevation, thus reducing the ice melt that is the main contribution to the Sabbione reservoir. The expected increase of precipitation is not sufficient to compensate ice melt decrease. Campliccioli water surface elevation in decade 2041-2050, on the contrary, does not show a similar decrease respect to decade 2001-2010. Glaciers depletion does not affect reservoirs that are mainly supplied by precipitation that, indeed, is expected to increase. The seasonal shift of precipitation that shows an increase of precipitation in winter and a decrease in summer seems not to impact the regulation of this kind of reservoirs.
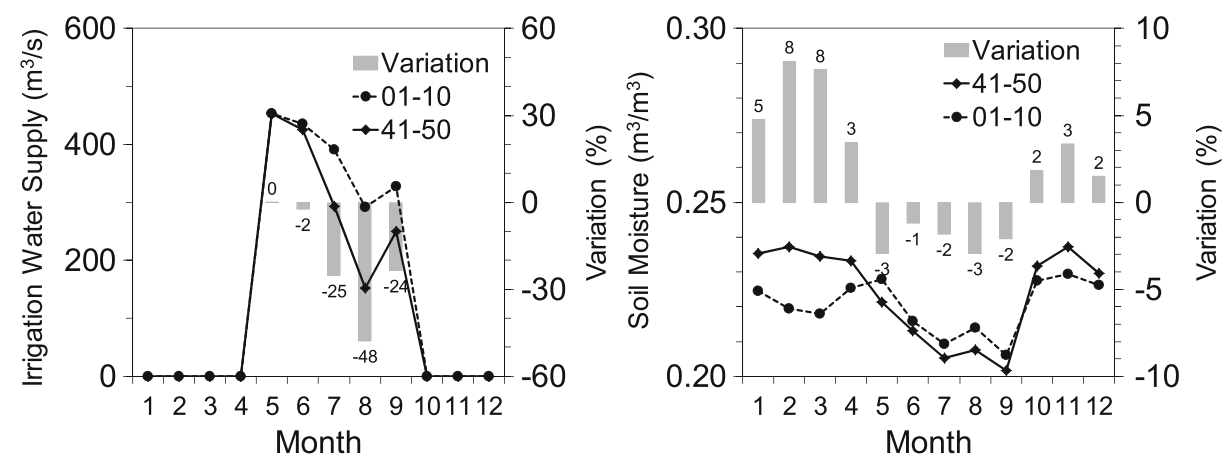

Fig. 12 Mean predicted monthly irrigation water supply and soil moisture of irrigated land for 2041-2050 as simulated by FEST-WB model driven by climate scenario compared to those simulated for 2001-2010 
(a)

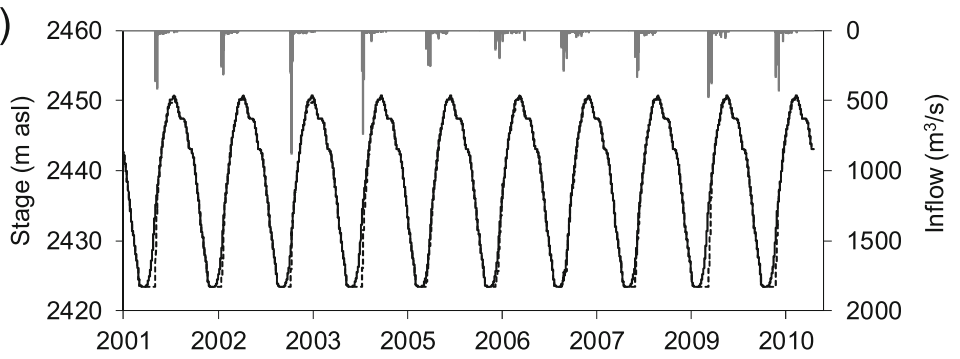

(b)

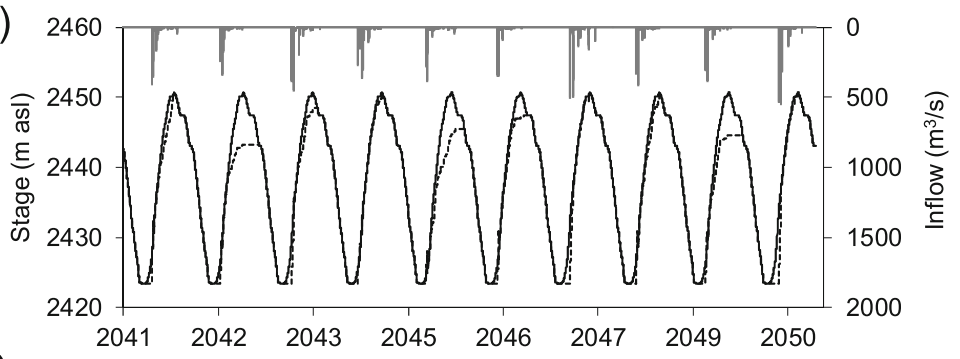

(c) 1370 m

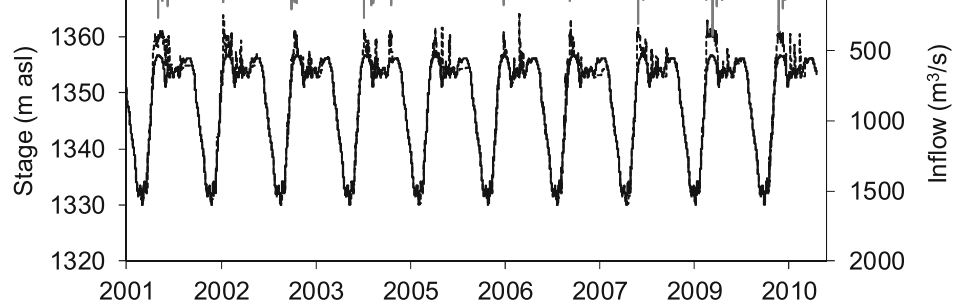

(d) 1370 Tा"

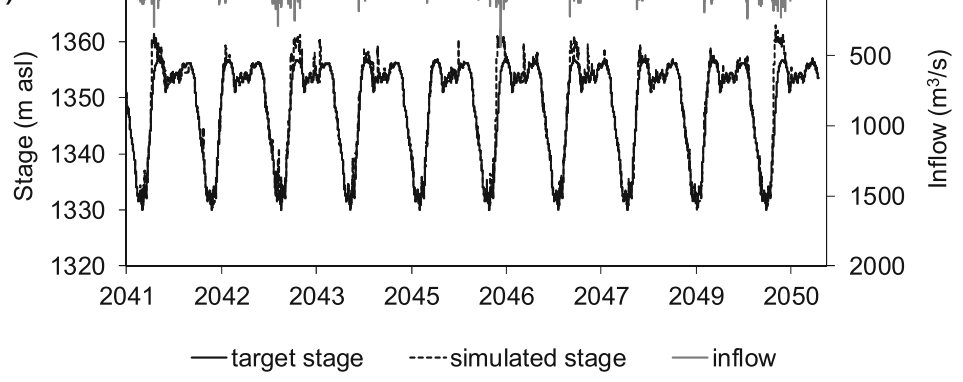

Fig. 13 Simulated and target stages within ice-melt-fed Sabbione dam (a and b) and rain-fed Campliccioli dam (c and d) for the two decades spanning 2001-2010 and 2041-2050

\subsection{Impacts on Groundwater Detention}

Impact on groundwater detention is assessed by computing the Groundwater Resource Index (GRI) often used to assess status of groundwater resources and drought condition over a specific area (Mendicino et al. 2008). GRI is defined as:

$$
\mathrm{GRI}_{y, m}=\frac{D_{y, m}-\mu_{D, m}}{\sigma_{D, m}}
$$


where $\mathrm{GRI}_{y, m}$ and $D_{y, m}$ are respectively the values of the index and of the groundwater detention for the year $y$ and the month $m$, while $\mu_{D, m}$ and $\sigma_{D, m}$ are respectively the mean and the standard deviation of groundwater detention values $D$ simulated for the month $m$ in the period 2001-2050.

The GRI was calculated for each cell of the unconfined aquifer for the period spanning 2001-2050. The mean GRI for each month is shown in Fig. 14 as well as the decadal average. Reference period (2001-2010) is characterized by minimum negative values of GRI. Important increase is expected in decade 2011-2020, followed by an alternation between positive and negative values of decadal average of GRI in the subsequent decades. The increase of annual precipitation, not compensated by the increase of evapotranspiration, is responsible of an average increment of groundwater detention. In order to provide an example of the spatial distribution of the index, in Fig. 15 the map of GRI for July 2041 is shown. Negative values of GRI can be observed alongside the river because of expected decrease of river discharge in summer that causes an increase of water withdrawn from unconfined aquifer leading to a decrease of groundwater detention in the cells next to the channel network. GRI is positive on $80 \%$ of groundwater. Mean value equals 0.4064 that is equivalent to a surplus of groundwater detention respect to the average condition of July of about $30010^{6} \mathrm{~m}^{3}$.

\section{Summary and Conclusions}

In this study we showed the importance of using an integrated spatially distributed physically based hydrological model capable to keep into account anthropogenic structures and management practices that interact with hydrological processes to investigate interconnection of changes due to climate warming.

The hydrological model, forced by both observed meteorological time series and climatic scenario, proved good accuracy in simulating dominant natural hydrological processes and anthropogenic disturbances as well.

Assessment of impact on hydrological balance showed that an increase of snow water equivalent is expected in winter and early spring compensated by an accelerated melt rate in late spring. An increase of actual evapotranspiration of about $3.5 \%$ is expected on annual basis. This is caused by an average $8.3 \%$ increase of precipitation mainly concentrated in winter and an average $1.3{ }^{\circ} \mathrm{C}$ increase of mean annual temperature. During the summer and spring, the climate model predicted a remarkable decrease in precipitation.

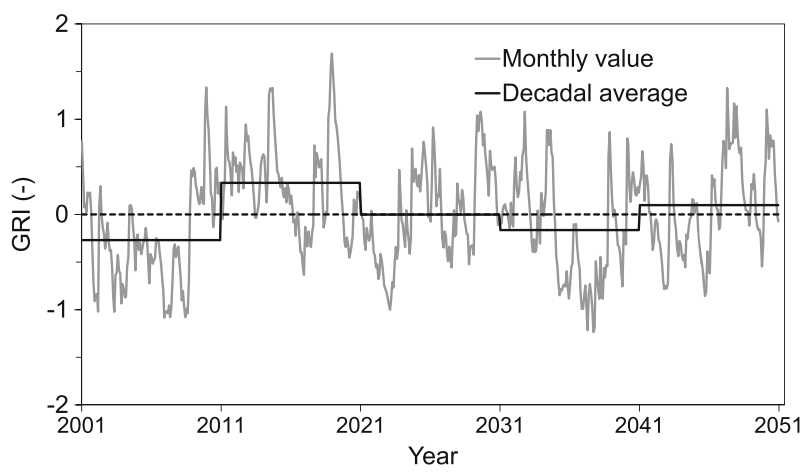

Fig. 14 Monthly value and decadal average of groundwater resource index (GRI) projected for the period spanning 2001-2050 


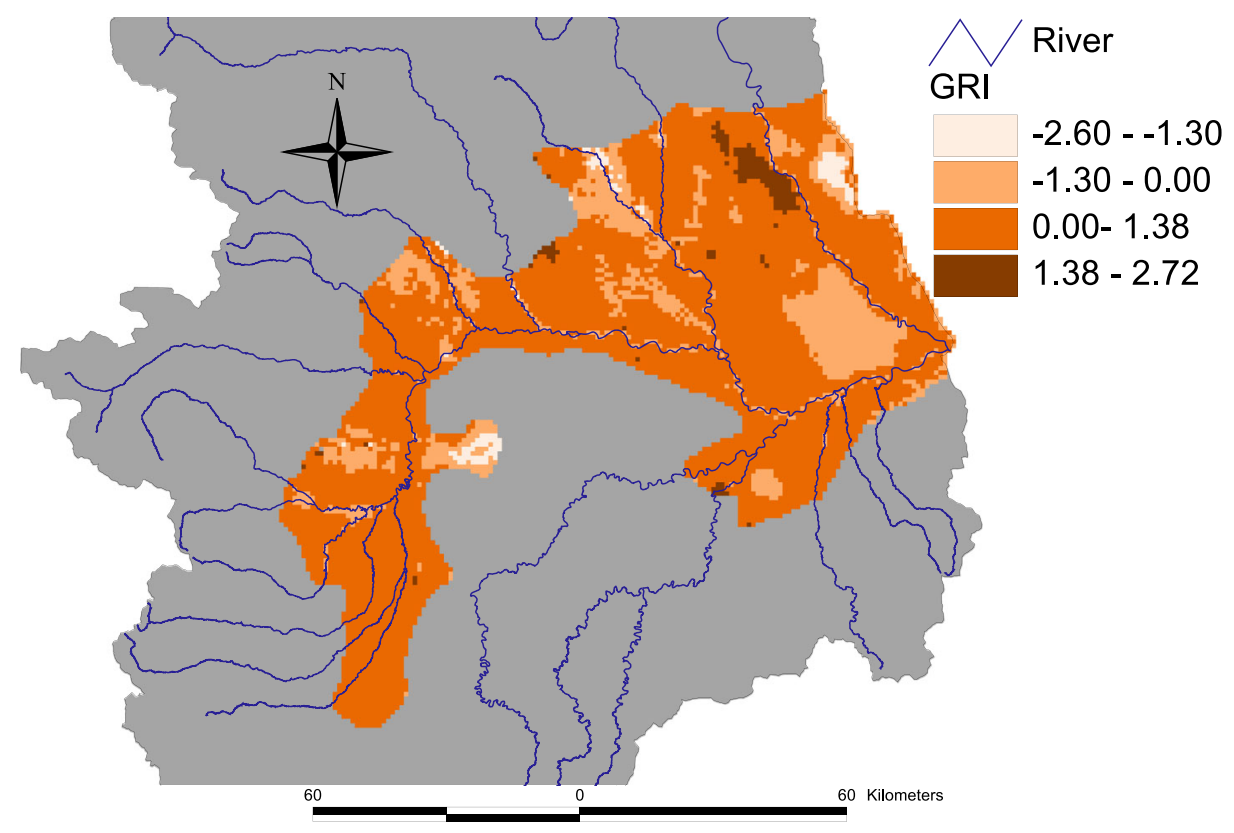

Fig. 15 Groundwater resource index distribution projected in July 2041 shown as representative of expected groundwater storage during summer

The seasonal shift observed in the precipitation was reflected in the predicted monthly discharge, with a remarkable increase expected in winter and autumn and an important decrease expected in summer. The direct consequence is a drastic reduction of water supply for irrigation purpose that, if no change will occur in cultivated species, may cause an important decrease of crop yield.

Simulation showed a constant decrease of glaciers volume till a new equilibrium of about $5.710^{9} \mathrm{~m}^{3}$ reached in 2025 starting from the initial value of $9.610^{9} \mathrm{~m}^{3}$. The minimum elevation of the lowest point of the glaciers over the Upper Po river basin is expected to increase from $1890 \mathrm{~m}$ asl in 2001 to about $2850 \mathrm{~m}$ asl after 2025 . No more increase of minimum glaciers elevation is expected after 2025. This can affect regulation of large artificial reservoirs, with implications on hydropower production and, more generally, on political strategies dedicated to the increase of percentage of electricity production from renewable sources.

The increase of annual precipitation is responsible of an average increment of groundwater detention that can become a strategic source of water as supplement to diminished river discharge for irrigation purposes during summer.

The limitation of this study is that one single climate scenario was used to assess the impacts on water resources. This study focused on investigating effectiveness of the use of an integrated distributed physically based hydrological model able to simulate hydrological processes and main anthropogenic disturbances under climate change. Future developments will include the use of climate scenarios generated by stochastic models in order to assess uncertainty and significance of the expected impacts.

Results of climate changes impacts on water resources availability can be transferred to alpine areas characterized by the same temperature and precipitation change and shift. The hydrological model, driven by climate projections, can be used for assessing climate change 
impacts on hydrological processes in many areas of the world even where anthropogenic structures and management practices that interact with natural hydrological cycle such as artificial regulated reservoirs and agricultural irrigation are present.

Acknowledgments The work was supported in the framework of the ACQWA EU/FP7 project (grant number 212250) "Assessing Climate impacts on the Quantity and quality of Water". Consorzio Ticino is acknowledged for providing record of daily net inflow to the Lake Verbano. The authors thank Chiara Dionisio and Rossana Zanchi for the contribution in data elaboration, and the two anonymous reviewers for their helpful comments that contributed to improve the paper.

\section{References}

Arnold JG, Allen PM, Bernhardt G (1993) A comprehensive surface-groundwater flow model. J Hydrol 142:47-69 Bencala KE, Gooseff MN, Kimball BA (2011) Rethinking hyporheic flow and transient storage to advance understanding of stream-catchment connections. Water ResourRes 47:W00H03 Beniston M (2012) Impacts of climatic change on water and associated economic activities in the Swiss Alps. J Hydrol 412:291-296 Beniston M, Uhlmann U, Goyette S, Lopez-Moreno JI (2011) Will snow-abundant winters still exist in the Swiss Alps in an enhanced greenhouse climate? Int J Climatol 31:1257-1263 Boscarello L, Ravazzani G, Mancini M (2013) Catchment multisite discharge measurements for hydrological model calibration. Procedia $\quad$ Environ $\quad$ Sci 19:158-167 Boscarello L, Ravazzani G, Rabuffetti D (2014) Integrating glaciers dynamics raster based modelling in large catchments hydrological balance: the Rhone case study. Hydrol Process 28(3):496-508. doi:10.1002/ hyp. 9588

Bove A, Casaccio D, Destefanis E, De Luca DA, Lasagna M, Masciocco L, Ossella L, Tonussi M (2005) Idrogeologia della pianura piemontese "Hydrogeology of Piemonte plain". Regione Piemonte, Mariogros Industrie Grafiche S.p.A, Torino, p 15

Camporese M, Paniconi C, Putti M, Orlandini S (2010) Surface-subsurface flow modeling with pathbased runoff routing, boundary condition-based coupling, and assimilation of multisource observation data. Water Resour Res 46, W02512. doi:10.1029/2008WR007536

Candela L, von Igel W, Elorza FJ, Aronica G (2009) Impact assessment of combined climate and management scenarios on groundwater resources and associated wetland (Majorca, Spain). J Hydrol 376:510-527

Capell R, Tetzlaff D, Essery R, Soulsby C (2014) Projecting climate change impacts on stream flow regimes with tracer-aided runoff models - preliminary assessment of heterogeneity at the mesoscale. Hydrol Process 28: 545-558. doi:10.1002/hyp.9612

Carnahan B, Luther HA, Wilkes JO (1969) Applied numerical methods. Wiley, New York Ceppi A, Ravazzani G, Salandin A, Rabuffetti D, Montani.A. Borgonovo. E, Mancini M (2013) Effects of Earth Syst 13(4):1051-1062 doi:10.5194/nhess-13-1051-2013

Chow VT, Maidment DR, Mays LWi:(1988) Applied hydrology. McGraw-Hill, New York

Christensen F D (2004) Coupling between the river basin management model (MIKE BASIN) and the 3D hydrological model (MIKE SHE) with use of the OpenMI system, in $6^{\text {th }}$ International Conference on Hydroinformatics, Singapore

Daniluk TL, Lautz LK, Gordon RP, Endreny TA (2013) Surface water-groundwater interaction at restored streams and associated reference reaches. Hydrol Process 27:3730-3746. doi:10.1002/hyp.9501 Debernardi L, De Luca DA, Lasagna M (2008) Correlation between nitrate concentration in groundwater and parameters affecting aquifer intrinsic vulnerability. Environ Geol 55(3):539-558. doi:10.1007/s00254-0071006-1

Dedieu JP, Lessard-Fontaine A, Ravazzani G, Cremonese E, Shalpykova G, Beniston M (2014) Shifting mountain snow patterns in a changing climate from remote sensing retrieval. Sci Total Environ. doi:10. 1016/j.scitotenv.2014.04.078

Di Baldassarre G, Montanari A (2009) Uncertainty in river discharge observations: a quantitative analysis.Hydrol Earth Syst Sci 13:913-921. doi:10.5194/hess-13-913-2009

Diolaiuti G, Bocchiola D, Magliasindi M, D’Agata C, Smiraglia C (2012) The 1975-2005 glacier changes in Aosta Valley (Italy) and the relations with climate evolution. Prog Phys Geogr 36(6):764-785. doi: $10.1177 / 0309133312456413$ 
Döll P (2002) Impact of climate change and variability on irrigation requirements: a global perspective. Clim Chang 54(3):269-293. doi:10.1023/A:1016124032231

Fatichi S, Rimkus S, Burlando P, Bordoy R, Molnar P (2013) Elevational dependence of climate change impacts on water resources in an Alpine catchment. Hydrol Earth Syst Sci Discuss 10:3743-3794. doi:10.5194/ hessd-10-3743-2013

Finger D, Heinrich G, Gobiet A, Bauder A (2012) Projections of future water resources and their uncertainty in a glacierized catchment in the Swiss Alps and the subsequent effects on hydropower production during the 21st century. Water Resour Res 48. doi:10.1029/2011WR010733

Fiseha BM, Setegn SG, Melesse AM, Volpi E, Fiori A (2014) Impact of climate change on the hydrology of Upper Tiber river basin using bias corrected regional climate model. Water Resour Manag 28:1327-1343. doi:10.1007/s11269-014-0546-x

Francés F, Vélez JI, Vélez JJ (2007) Split-parameter structure for the automatic calibration of distributed hydrological models. J Hydrol 332:226-240

Gaudard L, Romerio F, Dalla Valle F, Gorret R, Maran S, Ravazzani G, Stoffel M, Volonterio M (2014)

Climate change impacts on hydropower in the Swiss and Italian Alps. Sci Total Environ 493:1211-122.

doi:10.1016/j.scitotenv.2013.10.012

Gobiet A, Kotlarski S, Beniston M, Heinrich G, Rajczak J, Stoffel M (2014) 21st century climate change in the European Alps - a review. Sci Total Environ 493:1138-1151. doi:10.1016/j.scitotenv.2013.07.050

Graham DN, Butts MB (2005) Flexible, integrated watershed modelling with MIKE SHE. In Watershed Models, Eds. VP Singh \& DK Frevert, pp 245-272, CRC Press

Holman IP (2005) Climate change impacts on groundwater recharge - uncertainty, shortcomings, and the way forward? Hydrogeol J 14:637-647

Jacob D (2001) A note to the simulation of the annual and inter-annual variability of the water budget over the Baltic Sea drainage basin. Meteorog Atmos Phys 77:61-73

Kim NW, Chung IM, Won YS, Arnold JG (2008) Development and application of the integrated SWAT-MODFLOW MODEL. J Hydrol 356:1-16

Krause S, Bronstert A (2007) The impact of groundwater-surface water interactions on the water balance of a mesoscale lowland river catchment in northeastern Germany. Hydrol Process 21:169-184

Li L, Xu H, Chen X, Simonovic SP (2010) Streamflow forecast and reservoir operation performance assessment under climate change. Water Resour Manag 24:83-104. doi:10.1007/s11269-009-9438-x

McDonald MG, Harbaugh AW (1988) A modular three-dimensional finite-difference ground-water flow model. US Geological Survey Techniques of Water Resources Investigations Report Book 6, Chapter A1, p. 528

Mendicino G, Senatore A, Versace P (2008) A Groundwater Resource Index (GRI) for drought monitoring and forecasting in a Mediterranean climate. J Hydrol 357:282-302. doi:10.1016/j.jhydrol.2008.05.005

Nakicenovic N, Alcamo J, Davis G, de Vries B, Fenhann J, Gaffin S, Gregory K, Grbler A, Jung TY, Kram T,

La Rovere EL, Michaelis L, Mori S, Morita T, Pepper W, Pitcher H, Price L, Raihi K, Roehrl A, Rogner H-H, Sankovski A, Schlesinger M, Shukla P, Smith S, Swart R, van Rooijen S, Victor N, Dadi Z (2000) IPCC special report on emissions scenarios. Cambridge University Press, Cambridge

Nash JE, Sutcliffe JV (1970) River flow forecasting through the conceptual models, Part 1: a discussion of principles. J Hydrol 10(3):282-290

Pianosi F, Ravazzani G (2010) Assessing rainfall-runoff models for the management of Lake Verbano. Hydrol Process 24(22):3195-3205

Rabuffetti D, Ravazzani G, Corbari C, Mancini M (2008) Verification of operational Quantitative Discharge Forecast (QDF) for a regional warning system-the AMPHORE case studies in the upper Po River. Nat Hazards Earth Syst Sci 8:161-173. doi:10.5194/nhess-8-161-2008

Ravazzani G (2013) MOSAICO, a library for raster based hydrological applications. Comput Geosci 51:16 Ravazzani G, Giudici I, Schmidt C, Mancini M (2011a) Evaluating the potential of quarry lakes for supplemental irrigation. J Irrig Drain Eng 137(8):564-571. doi:10.1061/(ASCE)IR.1943-4774.0000321

Ravazzani G, Rametta D, Mancini M (2011b) Macroscopic cellular automata for groundwater modelling: a first approach. Environ Model Softw 26(5):634-643. doi:10.1016/j.envsoft.2010.11.011

Ravazzani G, Corbari C, Morella S, Gianoli P, Mancini M (2012) Modified Hargreaves-Samani equation for the assessment of reference evapotranspiration in Alpine river basins. J Irrig Drain Eng 138(7):592-599. doi:10. 1061/(ASCE)IR.1943-4774.0000453

Ravazzani G, Bocchiola D, Groppelli B, Soncini A, Rulli MC, Colombo F, Mancini M, Rosso R (2014a) Continuous stream flow simulation for index flood estimation in an Alpine basin of Northern Italy. Hydrol Sci J. doi:10.1080/02626667.2014.916405

Ravazzani G, Ghilardi M, Mendlik T, Gobiet A, Corbari C, Mancini M (2014b) Investigation of climate change impact on water resources for an Alpine basin in Northern Italy: implications for evapotranspiration modeling complexity. Plos One 9(10):e109053. doi:10.1371/journal.pone.0109053 
Ravazzani G, Gianoli P, Meucci S, Mancini M (2014c) Assessing downstream impacts of detention basins in urbanized river basins using a distributed hydrological model. Water Resour Manag 28(4):1033-1044. doi: $10.1007 /$ s11269-014-0532-3

Schulla J (2007) Model description WaSiM (Water balance Simulation Model). Institute for Atmospheric and Climate Science, Zürich, p 181

Schulla J, Jasper K (2007) Model description WaSiM-ETH (Water balance Simulation Model ETH). Institute for Atmospheric and Climate Science, Zürich, 181

Senatore A, Mendicino G, Smiatek G, Kunstmann K (2011) Regional climate change projections and hydrological impact analysis for a Mediterranean basin in Southern Italy. J Hydrol 399:70-92.

doi:10.1016/j. jhydrol.2010.12.035

Stocker TF, Qin D, Plattner G-K, Alexander LV, Allen S K, Bindoff NL, Bréon F-M, Church JA, Cubasch U, Emori S, Forster P, Friedlingstein P, Gillett N, Gregory JM, Hartmann DL, Jansen E, Kirtman B, Knutti R, Krishna Kumar K, Lemke P, Marotzke J, Masson-Delmotte V, Meehl GA, Mokhov II, Piao S, Ramaswamy V, Randall D, Rhein M, Rojas M, Sabine C, Shindell D, Talley LD, Vaughan DG, Xie S-P (2013) Technical summary. In: Climate change 2013: the physical science basis. Contribution of working group I to the fifth assessment report of the intergovernmental panel on climate change. Cambridge University Press, Cambridge, United Kingdom and New York, NY, USA

Sulis M, Paniconi C, Rivard C, Harvey R, Chaumont D (2011) Assessment of climate change impacts at the catchment scale with a detailed hydrological model of surface-subsurface interactions and comparison with a land surface model. Water Resour Res 47, W01513. doi:10.1029/2010WR009167

Themeß1 MJ, Gobiet A, Heinrich G (2012) Empirical-statistical downscaling and error correction of regional climate models and its impact on the climate change signal. Clim Chang 112(2):449-468. doi:10.1007/s10584-011-0224-4

Vansteenkiste T, Tavakoli M, Ntegeka V, Willems P, De Smedt F, Batelaan O (2013) Climate change impact on river flows and catchment hydrology: a comparison of two spatially distributed models. Hydrol Process 27: 3649-3662. doi:10.1002/hyp.9480

Veijalainen N, Dubrovin T, Marttunen M, Vehviläinen B (2010) Climate change impacts on water resources and lake regulation in the Vuoksi watershed in Finland. Water Resour Manag 24:3437-3459. doi:10.1007/s11269-010-9614-z

Verbunt M, Gurtz J, Jasper K, Lang H, Warmerdam P, Zappa M (2003) The hydrological role of snow and glaciers in alpine river basins and their distributed modelling. J Hydrol 282:36-55

Warscher M, Strasser M, Kraller U, Marke G, Franz T, Kunstmann H (2013) Performance of complex snow cover descriptions in a distributed hydrological model system: a case study for the high Alpine terrain of the Berchtesgaden Alps. Water Resour Res 49(5):2619-2637. doi:10.1002/wrcr.20219

Winter TC, Harvey JW, Franke OL, Alley WM (1998) Ground water and surface water; a single resource. U.S, Geological Survey Circular, p 79

$\mathrm{Xu}$ C-Y (2000) Modelling the effects of climate change on water resources in central Sweden. Water Resour Manag 14:177-189

Zagonari F (2010) Sustainable, just, equal, and optimal groundwater management strategies to cope with climate change: insights from Brazil. Water Resour Manag 24:3731-3756. doi:10.1007/s11269-010-9630-z 